\title{
Textile from the Waste: An Overview of the State of the Art in the Leather Production Process
}

\author{
Erminia D'Itria* \\ Department of Designer, Rome, Italy
}

Submission: October 28, 2017; Published: November 27, 2017

*Corresponding author: Erminia D’Itria, Designer, Rome, Italy, Email: erm.ditria@gmail.com

\section{Opinion}

I believe that as human being, as individuals and communities we have an impact on our environment. It is a perfect system in which we live. The problem of the resources exploitation is a dangerous reality, the industrial production is a huge weight on the planet, from water pollution to energy use.

When we think about textiles and their production process people use to don't think about all the ecological implication that are connected to this system, they focus their attention on the final object (clothes, shoes, accessories). This article wants to analyse one of the world most popular textile: the leather. Leather is a very ancient material and a lot of people tends to think of it as an environmental friendly one because in the collective imagination it is a resulting material, but that's not true.

The leather production requests the use of a variety of chemicals that can be harmful if worked off in the wrong way. Today tanks to different organizations and their reports, that monitor environmental issues, we know that, especially in thirdworld countries, there are pollution problems in the leather industry that the current laws cannot solve. The Green Cross Switzerland put the Leather tanneries at number four on the list the most dangerous sources of toxic pollution in the developing world.

It is emblematic that this position is just behind battery recycling, lead smelting and mining and ore processing. All factors that easily are related to their dangers. The Blacksmith Institute, one of the most important no-profit organization that fight against the pollution, has proved that there are almost 100 sites around the world that have been, or are being, polluted by tanneries. This not supervised contamination could potentially threatens more than two million people.

The process that transforms an animal hide into a piece of textile requires a series of chemical treatments: a. The hide is soaked in an alkaline solution containing sodium sulfide to remove hairs. b. The solution $\mathrm{pH}$ is reduced to 9 or 10 with salts like ammonium chloride, and then it's acidified all the way to $\mathrm{pH}$ 3 or 3.5 with acids like sulfuric acid.

c. After been soaked, the skin is treated with tanning agents (trivalent chromium sulfate).

d. The tanning agent stabilizes the leather and imparts desirable properties like flexibility and durability.

e. Chemicals like sodium formate are then added to neutralize any remaining acid, the leather is dyed with one of a wide range of dyes, and the manufacturer applies a surface coating, usually a reactive oil, to give the leather the desired finish and help to preserve it.

At the end, there are different tanning wastes that include strongly alkaline or basic mixtures, strongly acidic mixtures, sulfides and chromium salts [1]. All these substances are highly noxious. If a tannery is properly managed, the waste will be handled in a way that avoids pollution. The acidic and basic mixtures should be neutralized and the sulfides should be oxidized to sulfates. Chromium tanning liquors can be re-used so the chromium they contain can be recovered. All these steps are complex and in the developed countries there are specific regulations but there is a big part of our world where all this does not happen.

In poorer countries, where there are a lot of small tanneries, people cannot afford proper pollution control and for this reason they discharge their waste directly into dump sites [2]. India is one of these countries and in the recent years the city of Kanpur is became a case study thanks to its level of pollution.

In the last ten years the reports show that there is a very dangerous level of hexavalent chromium that is highly hazardous to both human and animal health. This substance is the result of the oxidation of the trivalent chromium that is in these wastes [3]. These kinds of pollution problems, could be easily solved but requires stricter standards in developing nations and possibly 
training for tannery owners and operators to ensure they know how to properly dispose of their waste.

Unfortunately, we are going to a future where this kind of solution will not be enough and this is why we need technology and research to aid the industry to convert/transform their production process and even the final product itself.

In this scenario, the 2017 Global Change Award, contest powered by the Swedish brand H\&M and its foundation is a very interesting case study [4-6]. This year the winner is an Italian project called Grape Leather that is an innovative vegetal leather that is made starting from the grapes and the wine wastes.

Vegea is the Italian company that has created and is developing this idea. The company is born in 2016, its founder Gianpiero Tessitore studied the physical and mechanical properties of various plant fibers, and their ability to be transformed into ecofriendly materials. His research result is "wineleather" a sturdy and real-feeling vegetal leather made from the grape skins, stalks, and seeds. Annually there are almost 26billion liters of wine produced in Italy that create a ton of organic waste and Vegea is using it to make a fashion forward product.

This is the perfect result of the joint work of different competences: design, chemistry and economy. This product guarantees the safety of the animals and prevent the use of the chemical products [7-8]. The impact of the leather on the environment is almost zero and it leads to a virtuous cycle that starts and ends in the soil.

This idea has changed the way the system thinks and produces this kind of textile therefore it is successful [9]. The design is able in this situation of trespassing the simple ethical question and give industry a way to think and act in favour of the Earth.

Even if it is in an embryonal state the Grape Leather shows the potentiality of the union of new technology and engineering to produce a positive model that can be followed and used by the others. The innovation and the bond between the different disciplines and the exchange of knows lead the way to a conscious and proper life style.

\section{References}

1. Pure Earth and Green Cross Switzerland (2016) World's Worst Pollution Problems.

2. Bailey DG (Ed.), (1999) Science and Technology for Leather into the Next Millennium. McGraw-Hill, India 1999: 283.

3. S Dasgupta (Ed.), (1991) Proceedings of the $25^{\text {th }}$ Leather Exposition. Indian Leather Technologists' Association, India pp. 43-71.

4. Subramanian Senthilkannan Muthu (Ed.), (2014) Roadmap to Sustainable Textiles and Clothing Environmental and Social Aspects of Textiles and Clothings Supply Chain, Springer, Germany.

5. United Nations Industrial Development Organization (2010) Future Trends in the World Leather and Leather Products Industry and Trade, Vienna, Austria.

6. Kurian Joseph, Nithya N (2008) Material flows in the life cycle of leather. Journal of Cleaner Production 17(7): pp. 676-682.

7. Richard S Blackburn (2009) Sustainable Textiles. Life Cycle and Environmental Impact, Woodhead Publishing, UK.

8. Khwaja AR, Rashmi Singh, Tandon SN (2001) Monitoring of Ganga Water and Sediments Vis-à-Vis Tannery Pollution at Kanpur (India): A Case Study. Environmental Monitoring and Assessment 68(1): pp 19-35.

9. Vegea srl (2017) Piazza Manifattura 1, 38068 Rovereto, Italy.
Your next submission with Juniper Publishers will reach you the below assets

- Quality Editorial service

- Swift Peer Review

- Reprints availability

- E-prints Service

- Manuscript Podcast for convenient understanding

- Global attainment for your research

- Manuscript accessibility in different formats

( Pdf, E-pub, Full Text, Audio)

- Unceasing customer service

Track the below URL for one-step submission https://juniperpublishers.com/online-submission.php 